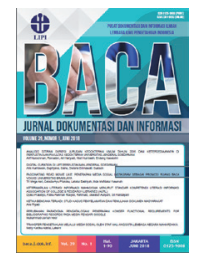

\title{
Karakteristik kepenulisan artikel pada Jurnal Agrisep Universitas Bengkulu tahun 2015-2019 menggunakan kajian bibliometrika
}

\author{
Bezisokhi Zendrato ${ }^{1}$ : Purwaka $^{2}$; Fransiska Timoria Samosir ${ }^{3}$ \\ 1,2,3 Universitas Bengkulu \\ *Korespondensi: ftsamosir@unib.ac.id
}

Diajukan: 09-01-2021; Direview: 02-02-2021; Diterima: 21-04-2021; Direvisi: 15-02-2021

\begin{abstract}
The purpose of this study is to know the characteristics of authorship and articles in the Journal AGRISEP at University of Bengkulu in 2015-2019 by using a study of bibliometrics based on several indicators. This research uses a descriptive quantitative study. This research uses bibliometric studies with statistical datas on the processing of research result. The object is articles in the AGRISEP Journal of University of bengkulu in 2015-2019 with a total of 91 articles. Data were analyzed by using frequency tabulations. The results of this research show that the characteristics of writing and articles in the Journal of University of Bengkulu AGRISEP in 2015-2019 is vary greatly. It shows that the authors were male (54.08\%). Most of the authors work as Lecturers $(50.43 \%$.) and have master educational background (46,49\%). Most of the articles were written by 3 authors (52,75\%). Most of the articles use Indonesian language (96.70\%.). The author with the highest productivity is Sriyoto. The most published articles were with a total of 31 articles in 2019. Most of the length of articles contain in this journal was 11-15 pages (56.15\%). Articles contain 3 keywords were (51.14\%), and the abstract length is around 150-199 words $(35.16 \%)$. Most of the literature sources used in this journal is journal articles with 373 citations $(36,93 \%)$. The characteristics of the writing and the articles show an overview that the development of articles in the AGRISEP journal, University of Bengkulu in 2015-2019 have met the guidelines that been determined.
\end{abstract}

\begin{abstract}
ABSTRAK
Tujuan penelitian untuk mengetahui karakteristik kepenulisan dan artikel pada jurnal artikel AGRISEP Universitas Bengkulu tahun 2015-2019 dengan menggunakan kajian Bibliometrika dengan beberapa indikator. Penelitian ini menggunakan penelitian kuantitatif deskriptif. Penelitian ini menggunakan kajian bibliometrika yang berkaitan dengan angka-angka pada pengolahan hasil penelitian. Objek penelitian ini adalah artikel dalam jurnal AGRISEP Universitas Bengkulu tahun 2015-2019 dengan jumlah 91 artikel. Data dianalisis dengan menggunakan tabulasi frekuensi. Hasil penelitian ini menunjukkan bahwa karakteristik kepenulisan dan artikel pada jurnal AGRISEP Universitas Bengkulu tahun 2015-2019 sangat bervariasi dilihat dari indikator yaitu penulis laki laki $(54,08 \%)$. Mayoritas pengarang memiliki profesi sebagai Dosen $(50,43 \%)$ dan memiliki latar belakang pendidikan Master $(46,49 \%)$. Sebagian besar artikel ditulis oleh 3 penulis $(52,75 \%)$. Bahasa yang digunakan sebagian besar adalah Bahasa Indonesia $(96,70) \%$. Tingkat produktivitas pengarang yang paling tinggi dipegang oleh Sriyoto. Artikel yang paling banyak terbit adalah pada tahun 2019 yaitu sejumlah 31 artikel. Sebagian besar artikel pada jurnal ini (56,15\%) memiliki panjang 11-15 halaman. Penggunaan kata kunci yaitu 3 kata kunci $(51,14 \%)$ dan panjang abstrak sekitar 150-159 (35,16\%). Sumber literatur pada jurnal ini paling banyak yaitu jurnal dengan 373 sitasi $(36,93 \%)$. Karakteristik kepenulisan dan artikel yang diperoleh menunjukkan gambaran perkembangan artikel dalam jurnal AGRISEP Universitas Bengkulu tahun 2015-2019 telah memenuhi panduan yang telah ditentukan.
\end{abstract}

Keywords: Authorship; Articles; Journals; Bibliometrics

\section{PENDAHULUAN}

Perkembangan ilmu pengetahuan dewasa ini sangat pesat dalam berbagai bidang ilmu pendidikan. Pesatnya perkembangan ilmu pengetahuan tersebut, didukung dengan meningkatnya karya dan kreativitas ilmiah oleh para ilmuwan dan akademisi. Berbagai peneliti dengan berbagai latar belakang 
pendidikan dan profesi, mulai dari mahasiswa, staf, dan dosen juga melakukan penelitian dalam berbagai bidang ilmu pengetahuan, seperti: bidang kesehatan, bidang sosial, bidang ekonomi, serta bidang pertanian dengan tujuan untuk memecahkan suatu masalah.

Menurut Guninda (2015:2) jurnal ilmiah merupakan media informasi yang penting dalam perkembangan ilmu pengetahuan. Jurnal merupakan terbitan berkala yang berisi tulisan ilmiah yang terbit pada kala waktu tertentu. Setiap artikel dalam jurnal dipublikasikan memiliki ciri khas atau karakteristik tertentu baik dalam penulisan maupun artikel. Karakteristik dalam penulisan dalam penelitian merupakan sifat atau ciri khas yang menggambarkan sesuatu secara detail, rinci dan menyeluruh sehingga dapat dipahami dan dimengerti. Demikian pula dengan karakteristik kepenulisan dan kepengarangan. Menurut Aliyu (2011:32) kepengarangan merupakan salah satu aspek yang berperan penting dalam penyebaran informasi dan komunikasi. Kontribusi penulis dapat dilihat dari pola yang berbeda, seperti penulis tunggal, penulis bersama dan beberapa penulis. Setiap artikel jurnal disajikan oleh satu orang atau lebih yang bertindak sebagai penulis. Penulis artikel adalah orang yang menulis atau membuat artikel, sedangkan kepenulisan adalah perihal penulis atau segala sesuatu yang berkaitan dengan penulis (Irianti, 2017:30).

Karakteristik suatu artikel di dalam jurnal juga menjadi pertimbangan kelayakan publikasi bagi perguruan tinggi. Hal ini dibuktikan dengan adanya panduan penulisan terkait panjangnya artikel atau halaman dari jurnal, kata kunci, daftar tabel dan gambar, dan panjang abstrak yang diperoleh dari penelitian. Dewasa ini, bahkan peneliti banyak menggunakan Bahasa Inggris dalam penulisan artikel dalam menyajikan hasil penelitiannya. Selain itu, subjek penelitian juga menjadi penentu publikasi sebuah artikel dalam bentuk jurnal. Setiap perguruan tinggi yang akan mempublikasikan sebuah jurnal, juga perlu memperhatikan kualitas penulisan artikel, serta literatur rujukan dalam jurnal. Layak atau tidaknya suatu jurnal untuk diterbitkan menjadi suatu perhatian khusus dalam publikasi, penilaian dalam artikel juga meliputi sumber dan jenis literatur yang digunakan peneliti.

Artikel dalam jurnal pada umumnya berupa hasil-hasil penelitian bidang-bidang yang lebih spesifik atau khusus (Saleh dalam Junandi, 2010:17). Menurut Jatmiko et al., (2015:85) sistematika penulisan merupakan aturan atau tata cara yang digunakan dalam menulis artikel ilmiah sesuai kaidah yang disepakati. Setiap jurnal ilmiah maupun konferensi ilmiah biasanya mempunyai aturan sistematika penulisan masing-masing. Akan tetapi, secara umum semuanya memiliki kesamaan dalam bagian-bagian utama penulisan. Sistematika penulisan artikel dalam jurnal terdiri dari judul, identitas penulis, nama penulis, fakultas (universitas/kampus, alamat), abstrak, kata kunci, pendahuluan, metodologi penelitian, hasil dan analisis, kesimpulan dan saran, penghargaan (acknowledgment), referensi dan lampiran (appendix).

Perguruan tinggi merupakan salah satu instansi yang diharapkan mampu menghasilkan berbagai tulisan-tulisan yang diterbitkan di jurnal sebagai bentuk komunikasi ilmiah. Jurnal merupakan wadah bagi mahasiswa SI, S2, S3, staf, dan dosen dari perguruan tinggi dalam menghasilkan suatu karya - karya penelitian ilmiah. Setiap jurnal memiliki karakteristik kepenulisan yang akan mempengaruhi pertimbangan dalam publikasi.

Fakultas Pertanian Universitas Bengkulu merupakan salah satu bagian dari perguruan tinggi di Indonesia yang telah menerbitkan publikasi berkala yang bernama Jurnal AGRISEP dengan kajian masalah yang meliputi sosial, ekonomi, pertanian, dan agribisnis. Jurnal ini pada saat ini berada pada peringkat Sinta 3 Kemenristekdikti. Jurnal AGRISEP juga telah dipublikasi dalam Open Journal System (OJS) Universitas Bengkulu dan telah mendapatkan akreditasi Sinta 3. Jurnal ini juga berkontribusi untuk pengembangan ilmu sosial dan ekonomi pertanian di bidang agribisnis yang terbagi dalam Bahasa Indonesia dan Inggris yang berisi hasil penelitian. Jurnal AGRISEP terbit dua kali dalam setahun (Maret dan September) dengan nomor ISSN: p-ISSN 1412 - 8837 (cetak) dan e-ISSN 2579-9959 (online). 
Permasalahan dalam penelitian ini adalah bagaimana karakteristik kepenulisan dan artikel yang ada pada jurnal AGRISEP Universitas Bengkulu. Adapun yang menjadi indikator penelitian ini yaitu karakteristik kepenulisan yang terdiri dari jenis kelamin pengarang, instansi pengarang, profesi pengarang, dan latar belakang pendidikan pengarang yang ada di Jurnal AGRISEP Universitas Bengkulu tahun 2015-2019. Selain itu, indikator lain adalah karakteristik artikel yang mencakup panjang artikel, panjang abstrak, jumlah kata kunci, jumlah tabel dan gambar pada Jurnal AGRISEP Universitas Bengkulu tahun 2015-2019. Dengan demikian, berdasarkan karakteristik yang ditentukan maka akan ditemukan pola karakteristik kepenulisan dan artikel pada Jurnal AGRISEP Universitas Bengkulu tahun 2015-2019. Penelitian ini diharapkan dapat menjadi evaluasi bagi penerbitan Jurnal AGRISEP untuk meningkatkan kualitas akreditasi dan reputasi jurnal Jurnal AGRISEP. Selain itu, penelitian ini juga membantu perkembangan kajian bibliometrika khususnya bidang produktivitas pengarang.

\section{TINJAUAN PUSTAKA}

Kajian bibliometrika telah banyak digunakan oleh peneliti yang melakukan penelitian dibidang artikel untuk mengkaji perkembangan dan penulisan sebuah artikel. Menurut Pohan (2014:5), bibliometrika adalah suatu ilmu atau kajian mengenai suatu informasi yang terekam yang bersifat ilmiah dengan menggunakan metode statistika dan matematika. Selain itu, Pattah (2013:48) menyebutkan bahwa metode bibliometrika merupakan metode kajian yang bersifat deskriptif dengan melihat pola kepengarangan, biasanya digunakan untuk mengetahui jenis kelamin pengarang, jenis pekerjaan pengarang, tingkat kolaborasi, produktivitas pengarang, lembaga tempat pengarang bekerja, dan subyek artikel. Pendekatan bibliometrika digunakan untuk menganalisis nirkabel yang dikaji, yaitu sebaran artikel, profesi penulis, subyek artikel, kemutakhiran sitiran literatur, jenis sumber sitiran, tingkat kolaborasi penulis, dan produktivitas penulis. Salah satu syarat yang harus dipenuhi dalam analisis bibliometrika adalah artikel yang dianalisis harus dipublikasi dalam majalah ilmiah (Wibowo dalam Savitri, 2018:24).

Indikator bibliometrika merupakan pengetahuan yang mempunyai peranan untuk mengevaluasi hasil penelitian ilmiah, mengkaji interaksi antara ilmu pengetahuan dan teknologi, menghasilkan pemetaan bidang ilmu, melacak/ menelusuri perkembangan pengetahuan baru dalam bidang tertentu, serta merupakan indikator di masa depan dalam memberikan keuntungan yang lebih kompetitif dan dalam membuat rencana strategis. Indikator bibliometrik dihitung dalam periode waktu tertentu (biasanya 3 - 5 tahun) dan umumnya menggunakan dua pendekatan, yaitu jumlah publikasi, indikator yang mengukur produktivitas, dan jumlah kutipan, indikator yang mengukur dampak dari artikel yang dihasilkan (Devos dalam Tupan at al., 2018:136).

Berdasarkan penjelasan di atas maka untuk menjawab karakteristik pada Jurnal AGRISEP Universitas Bengkulu tahun 2015-2019 ditentukan beberapa indikator antara lain: karakteristik kepenulisan terdiri atas jenis kelamin, instansi asal dari penulis atau penerbit artikel dalam jurnal, jenis pekerjaan berdasarkan pada artikel dalam jurnal, jumlah penulis, tingkat pendidikan penulis, bahasa dan produktivitas pengarang. Sedangkan karakteristik artikel terdiri atas jumlah artikel, panjang artikel, jumlah kata kunci, banyak tabel dan gambar, dan panjang abstrak serta jenis-jenis literatur yang digunakan dalam jurnal AGRISEP Universitas Bengkulu tahun 2015-2019. Alasan pengambilan jurnal AGRISEP sebagai bahan penelitian dibandingkan dengan jurnal lain dalam Online Journal System Univeristas Bengkulu karena jurnal AGRISEP merupakan jurnal terakreditasi dan memiliki frekuensi terbit yang berkala, serta selalu memperhatikan perkembangan dan kualitas artikel yang akan dipublikasi pada jurnal. 


\section{METODE}

Penelitian ini merupakan penelitian kuantitatif deskriptif. Metode kuantitatif deskriptif menganalisis dan menyajikan data fakta secara sistematik sehingga dapat lebih mudah dipahami dan disimpulkan (Anwar dalam Irianti, 2017:32). Pengumpulan data dalam penelitian ini menggunakan metode dokumentasi dengan mengumpulkan data dan sumber-sumber tertulis yang dipublikasi secara online pada jurnal AGRISEP Universitas Bengkulu. Jumlah populasi dalam penelitian ini sekitar 118 artikel dan sampel sebanyak 91 sampel.

Pengambilan sampel dalam penelitian ini dilakukan dengan teknik probability sampling yaitu proportionate stratified random sampling dengan menggunakan rumus Slovin. Menurut Sugiyono dalam Aprilliana (2014:30), probability sampling adalah teknik pengambilan sampel yang memberikan peluang yang sama bagi setiap unsur (anggota) populasi untuk dipilih menjadi anggota sampel. Sumber data yang digunakan dalam penelitian ini adalah sumber data primer yaitu temuan langsung dari artikel-artikel yang dipublikasi dalam Jurnal AGRISEP Universitas Bengkulu.

\subsection{Analisis data}

Analisis data yang digunakan dalam penelitian ini adalah menggunakan kajian bibliometrika dengan metode kuantitatif deskriptif. Analisis data dalam penelitian ini menggunakan tabel frekuensi dalam persentase pada masing-masing indikator. Analisis data dilakukan setelah seluruh proses penelitian dilakukan dan data dikumpulkan. Selanjutnya, data tersebut diidentifikasi dan dikelompokkan berdasarkan indikator-indikator sesuai dengan rumusan masalah dalam penelitian, yaitu berdasarkan jenis kelamin, instansi asal, jenis pekerjaan, jumlah penulis, tingkat pendidikan penulis, bahasa, produktivitas pengarang, jumlah artikel, panjang artikel, jumlah kata kunci, banyak tabel dan gambar, panjang abstrak, dan jenis literatur yang digunakan dalam jurnal. Data selanjutnya dianalisis dengan memberi gambaran dari beberapa data dalam bentuk skor (jumlah), persentase dan kumulatif.

Penyajian data dalam penelitian ini dilakukan dengan menghitung nilai persentase dan kumulatif dari data tunggal. Selanjutnya, data dianalisis dengan menggunakan kajian bibliometrika dari seluruh data yang telah ditabulasi dalam tabel. Metode analisis data dalam penelitian ini dilakukan dengan menghitung nilai frekuensi relatif dan kumulatif data tunggal dari masing-masing indikator menggunakan rumus persentase sebagai berikut:

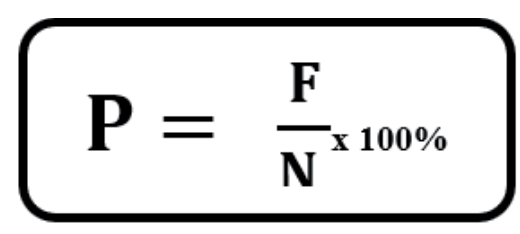

Keterangan:

$\mathrm{P}=$ Persentase (frekuensi relatif)

$\mathrm{F}=$ Jumlah atau Frekuensi

$\mathrm{N}=$ Jumlah Total

\section{HASIL DAN PEMBAHASAN}

Berdasarkan jumlah populasi artikel dalam jurnal AGRISEP Universitas Bengkulu tahun 20152019 sebanyak 118 artikel, jumlah artikel yang menjadi sampel penelitian sebanyak 91 artikel dengan tingkat signifikansi $5 \%(0,05)$. Berikut ini hasil penelitian yang dikelompokkan berdasarkan indikator-indikator dalam penelitian. 


\subsection{Karakteristik Kepenulisan pada Jurnal AGRISEP Universitas Bengkulu tahun 2015-} 2019.

\subsubsection{Jenis Kelamin}

Karakteristik kepenulisan berdasarkan jenis kelamin dianalisis untuk melihat berapa jumlah laki-laki dan perempuan yang berkontribusi dalam penulisan artikel di jurnal AGRISEP. Secara keseluruhan, kepenulisan artikel jurnal AGRISEP Universitas Bengkulu tahun 2015-2019 melibatkan 233 nama penulis dari 173 nama penulis yang berbeda. Jenis kelamin penulis dalam artikel ditentukan berdasarkan nama (dilakukan pencarian khusus untuk nama-nama penulis yang masih kurang jelas). Dalam kepenulisan artikel pada jurnal AGRISEP, jumlah penulis laki-laki lebih tinggi daripada penulis berjenis kelamin perempuan. Hal ini dapat dilihat dari gambar tabulasi di bawah ini.

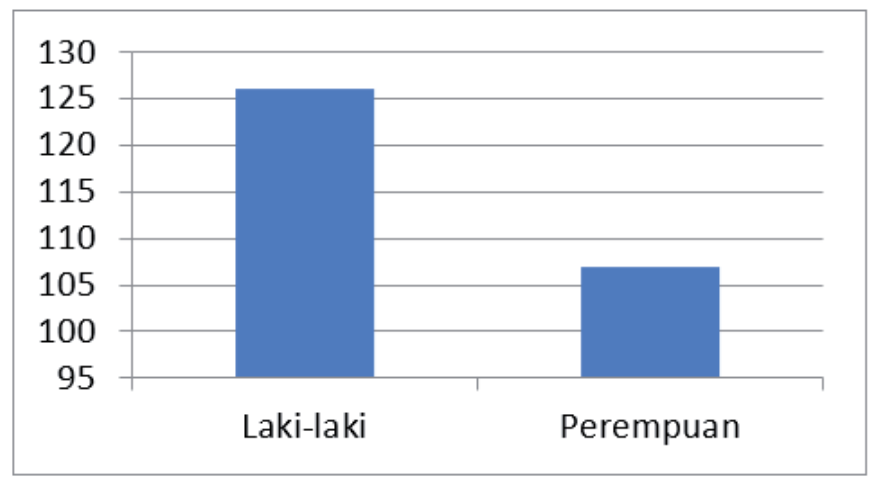

Gambar 1. Jumlah kepenulisan artikel jurnal AGRISEP Universitas Bengkulu tahun 2015-2019 berdasarkan jenis kelamin

Sumber: Data primer diolah, tahun 2020

Berdasarkan Gambar 1 terlihat bahwa keterlibatan penulis berjenis kelamin laki-laki lebih tinggi daripada penulis berjenis kelamin perempuan pada kepenulisan artikel jurnal AGRISEP Universitas Bengkulu tahun 2015-2019. Jumlah penulis laki-laki terdiri atas 126 orang (54,08 \%), sedangkan penulis yang berjenis kelamin perempuan terdiri atas 107 orang $(45,92 \%)$. Hal ini sependapat dengan penelitian yang dilakukan oleh Purnomowati dalam Irianti (2017:33) terhadap majalah ilmiah di Indonesia, yang menyatakan bahwa persentase penulis laki-laki lebih tinggi daripada penulis perempuan. Hal ini menunjukkan bahwa mayoritas pengarang yang berkontribusi dalam publikasi Jurnal AGRISEP adalah laki-laki. Hal ini dapat terjadi dikarenakan beberapa faktor, salah satunya kemungkinan perempuan memiliki peminatan dalam jurnal lain atau kontribusi pada bidang lain.

\subsubsection{Instansi Asal}

Penulis artikel dalam jurnal AGRISEP berasal dari berbagai instansi baik dari perguruan tinggi maupun badan instansi. Penulis dari perguruan tinggi pada fakultas bidang pertanian dan instansi bidang pertanian menjadi penulis paling banyak dalam jurnal ini. Terdapat 27 instansi yang terlibat dalam kepenulisan jurnal AGRISEP Universitas Bengkulu Tahun 2015-2019. Pengelompokkan instasi asal dalam penelitian ini terdiri atas instansi asal Universitas Bengkulu, instansi asal di luar Universitas Bengkulu dan instansi asal Badan Penelitian. 


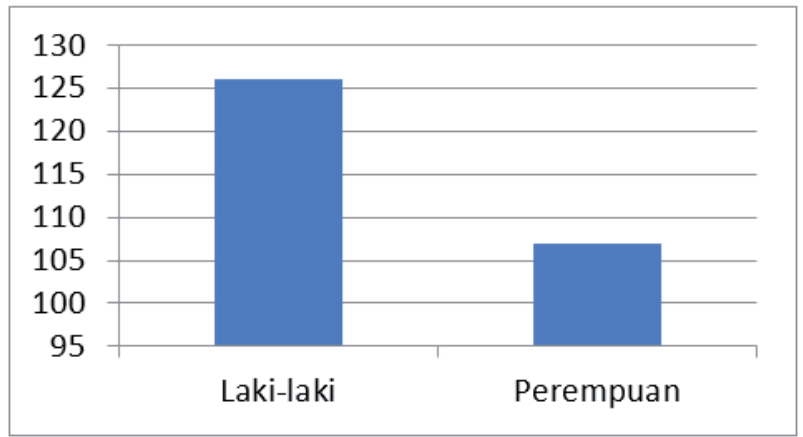

Gambar 2. Jumlah kepenulisan artikel jurnal AGRISEP Universitas Bengkulu tahun 2015-2019 berdasarkan instansi asal

Sumber: Data primer diolah, tahun 2020

Berdasarkan Gambar 2. terlihat bahwa penulis yang berasal dari Universitas Bengkulu sebanyak 102 orang $(43,59 \%)$, penulis yang berasal dari luar Universitas Bengkulu sebanyak 120 orang $(51,28 \%)$, dan penulis yang berasal dari Badan penelitian sebanyak 12 orang $(5,13 \%)$. Bila ditinjau dari jumlah artikel yang ditulis, maka Universitas Bengkulu menyumbang artikel yaitu sebanyak 41 artikel pada jurnal AGRISEP Universitas Bengkulu tahun 2015-2019. Hal ini sesuai dengan pendapat Irianti (2017:33) bahwa tingginya penulis internal dalam artikel menunjukkan bahwa ada kecenderungan perasaan memiliki di kalangan internal dengan berpartisipasi menyumbangkan karya tulisnya agar terjaga keberlangsungan penerbitan publikasi yang diterbitkan oleh lembaga induknya.

Dominasi penulis artikel dari Universitas Bengkulu menunjukkan antusiasme penulis internal. Kemudahan dalam mendaftar di institusi sendiri menjadi salah satu pertimbangan penulis-penulis dari internal institusi untuk menulis di jurnalnya sendiri. Selain itu, banyak juga mahasiswa Universitas Bengkulu yang menulis bersama dengan dosen pembimbing dan dipublikasikan ke jurnal AGRISEP.

\subsubsection{Jenis Pekerjaan}

Penulis artikel dalam jurnal AGRISEP Universitas Bengkulu tahun 2015-2019 berasal dari berbagai jenis kalangan dan latar belakang pekerjaan atau status yang berbeda. Jenis pekerjaan yang teridentifikasi terdiri dari dosen/ staf pengajar, mahasiswa, peneliti, dan konsultan pendidikan. Dari 91 artikel jurnal AGRISEP Universitas Bengkulu tahun 2015-2019, diperoleh bahwa 230 orang yang memiliki jenis pekerjaan yang terdiri atas dosen/staf pengajar, mahasiswa, peneliti, dan konsultan pendidikan.

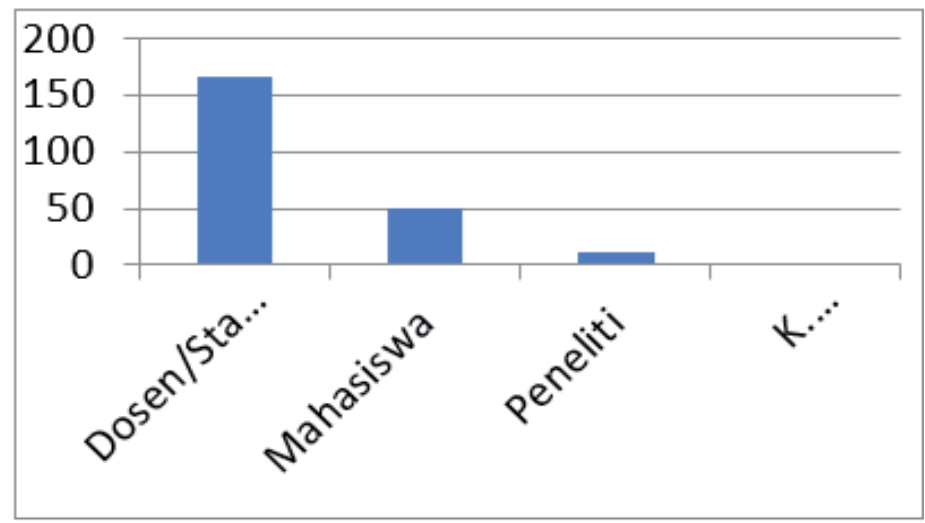

Gambar 3. Jumlah kepenulisan artikel Jurnal AGRISEP Universitas Bengkulu tahun 2015-2019 berdasarkan Jenis Pekerjaan

Sumber: Data primer diolah, tahun 2020 
Gambar 3. menunjukkan bahwa dari 91 artikel, penulis yang bekerja sebagai dosen/ staf pengajar terdiri atas 166 orang $(50,43 \%)$, sedangkan yang bekerja sebagai mahasiswa terdiri atas 51 orang $(22,17 \%)$, selanjutnya yang bekerja sebagai peneliti terdiri atas 12 orang $(5,22 \%)$, dan terakhir yang bekerja sebagai konsultan pendidikan terdiri atas 1 orang $(0,43 \%)$. Dari hasil tersebut dapat disimpulkan bahwa dosen memiliki kontribusi paling tinggi di jurnal AGRISEP yaitu sebanyak 166 orang dibanding profesi lain. Profesi yang paling sedikit berkontribusi dalam jurnal AGRISEP adalah peneliti dan konsultan pendidikan. Hal ini bisa terjadi karena kewajiban dosen dan profesi lain yang berbeda dalam publikasi ilmiah. Hal ini sependapat dengan pernyataan Nasir dalam Irianti (2017:34) yang menyebutkan bahwa dosen telah berpartisipasi meningkatkan publikasi karya ilmiah di Indonesia, meskipun secara kumulatif karya ilmiah di Indonesia yang berhasil dipublikasi belum mencapai target yang ditentukan.

Kontribusi dosen yang paling banyak pada penulisan artikel jurnal AGRISEP disebabkan berbagai faktor. Faktor pertama, universitas mewajibkan dosen yang merupakan akademisi mempublikasikan hasil-hasil laporan penelitiannya. Faktor lain adalah artikel pada jurnal AGRISEP 2015-2019 merupakan hasil dari skripsi mahasiswa yang ditulis kembali dalam jurnal, dimana dosen selaku pembimbing mahasiswa dicantumkan dalam kepenulisan artikel. Dengan demikian, dapat disimpulkan bahwa dosen telah melakukan kewajibannya terutama dalam publikasi karya ilmiah.

\subsubsection{Jumlah Penulis}

Jumlah penulis pada jurnal AGRISEP Univeristas Bengkulu tahun 2015-2019 cukup bervariasi. Dari 91 judul artikel pada jurnal terdapat enam kategori jumlah penulis antara lain: 1 penulis, 2 penulis, 3 penulis, 4 penulis, 5 penulis, dan $>5$ penulis. Berikut ini hasil temuan karakteristik kepenulisan berdasarkan jumlah penulis pada jurnal AGRISEP Universitas Bengkulu tahun 2015-2019.

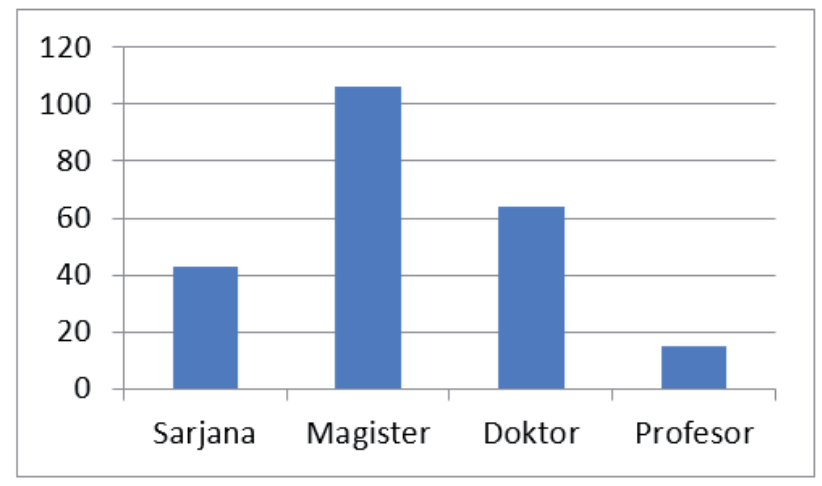

Gambar 4. Jumlah kepenulisan artikel jurnal AGRISEP Universitas Bengkulu tahun 2015-2019 berdasarkan jumlah penulis

Sumber: Data primer diolah, tahun 2020

Berdasarkan Gambar 4 terlihat bahwa penyajian artikel pada jurnal AGRISEP Universistas Bengkulu tahun 2015-2019 oleh 1 penulis terdiri atas 16 artikel (17,58 \%), sedangkan penyajian artikel oleh 2 penulis terdiri atas 20 artikel (21,98\%), selanjutnya penyajian artikel oleh 3 penulis terdiri atas 48 artikel (52,75\%), penyajian artikel oleh 4 penulis terdiri atas 4 artikel (4,39\%), penyajian artikel oleh 5 penulis terdiri atas 2 artikel (2,20\%), dan penyajian artikel oleh $>5$ penulis terdiri atas 1 artikel $(1,10 \%)$. Penulisan artikel lebih dari satu orang lebih tinggi dikarenakan penulis terdiri dari dosen dan mahasiswa, atau hanya dosen saja yang melibatkan lebih dari 1 orang penulis. Artikel jurnal dengan kolaborasi tiga pengarang juga memiliki persentase paling tinggi. Hal ini disebabkan pada umumnya penelitian memang terdiri dari tiga peneliti. Hal ini sesuai dengan pendapat Sri Wulan (2017:162) yang menyebutkan bahwa pola kepenulisan individu menduduki posisi rendah dalam memecahkan persoalan taksonomi hewan dibandingkan kelompok. 
Penulisan artikel jurnal AGRISEP tahun 2015-2019 mayoritas ditulis oleh lebih dari satu pengarang. Hal ini dipengaruhi oleh faktor bahwa dengan adanya kolaborasi dalam menulis sebuah karya ilmiah akan dihasilkan karya ilmiah yang baik karena karya ditulis oleh beberapa orang di dalamnya. Penelitian dosen pada umumnya juga dilakukan oleh beberapa peneliti sehingga penelitian yang dijurnalkan juga terdiri dari beberapa peneliti. Faktor lain adalah skripsi mahasiswa diterbitkan dalam bentuk jurnal sehingga penulisnya akan lebih dari satu orang. Dengan kata lain, penulisnya bukan hanya mahasiswa yang menjalankan penelitian itu melainkan juga dua penulis lainnya yaitu dosen yang membimbing. Hal ini yang menyebabkan penulis lebih dari satu orang lebih banyak di jurnal AGRISEP.

\subsubsection{Tingkat Pendidikan Penulis}

Berdasarkan 91 artikel pada Jurnal AGRISEP Universitas Bengkulu tahun 2015-2019 ditemukan 228 orang yang memiliki tingkat pendidikan antara lain sarjana, magister, doktoral dan profesor.

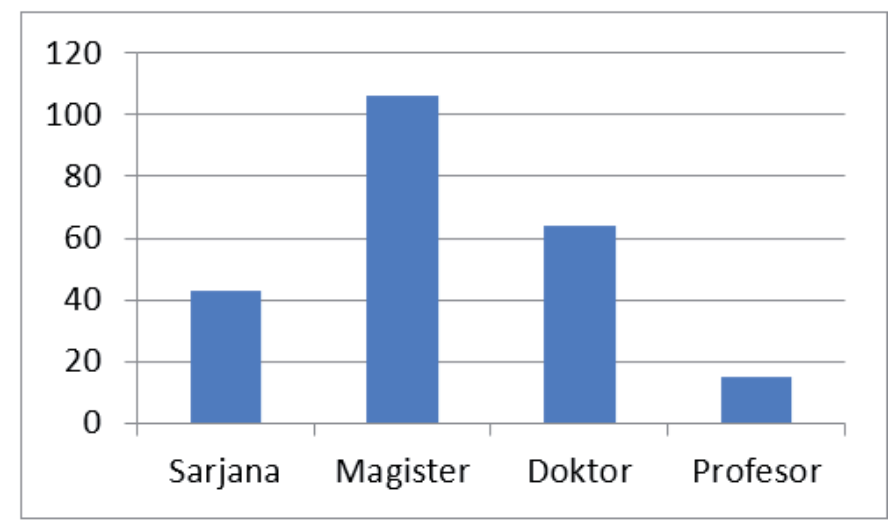

Gambar 5. Jumlah kepenulisan artikel Jurnal AGRISEP Universitas Bengkulu tahun 2015-2019 berdasarkan Tingkat Pendidikan Penulis

Sumber: Data primer diolah, tahun 2020

Berdasarkan Gambar 5, penulis yang memiliki tingkat pendidikan sarjana terdiri atas 43 orang $(18,86 \%)$, penulis yang memiliki tingkat pendidikan magister terdiri atas 106 orang $(46,49 \%)$, penulis yang memiliki tingkat pendidikan doktor terdiri atas 64 orang $(28,07 \%)$, dan penulis yang memiliki tingkat pendidikan profesor terdiri atas 15 orang $(6,58 \%)$. Hal ini dapat dilihat bahwa tingkat pendidikan magister memiliki kontribusi paling banyak dalam jurnal AGRISEP, disusul kemudian dengan pendidikan doktor.

Faktor yang menyebabkan Pendidikan S2 dan S3 lebih tinggi dikarenakan keterlibatan penulis dengan jenjang pendidikan ini sangat berpengaruh, yaitu dalam hal pengalaman, kemampuan, dan pengetahuan yang lebih dalam membimbing mahasiswa dalam melakukan penelitian. Ketika seorang mahasiswa strata satu menyelesaikan studi, maka ia harus dibimbing oleh dosen dengan latar belakang pendidikan magister atau doktor. Begitu pula dengan mahasiswa tingkat magister yang melakukan penelitian akan dibimbing oleh dosen berpendidikan doktor atau profesor.

Keterlibatan penulis berpendidikan magister dan doktor lebih banyak daripada sarjana pada artikel jurnal AGRISEP Universitas Bengkulu tahun 2015-2019. Hal ini juga sependapat dengan hasil penelitian Sutardji dalam Irianti (2017:35) bahwa penulis artikel yang berpendidikan S2 dan S3 lebih tinggi daripada penulis berpendidikan S1. Akan tetapi, hasil ini bisa berbeda ketika dikaji pada jurnal yang berbeda dengan subjek dan disiplin ilmu yang berbeda pula. 


\subsubsection{Bahasa}

Bahasa pengantar yang digunakan pada jurnal AGRISEP Universitas Bengkulu tahun 2015-2019 terdiri atas Bahasa Indonesia dan Bahasa Inggris. Berikut ini hasil analisis jumlah artikel yang menggunakan Bahasa Indonesia dan Bahasa Inggris sebagai bahasa pengantar dalam penulisan artikel.

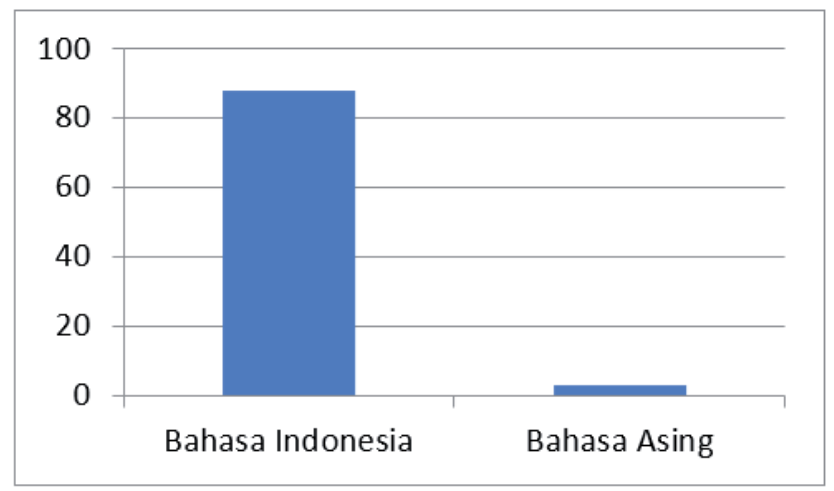

Gambar 6. Jumlah kepenulisan artikel Jurnal AGRISEP Universitas Bengkulu tahun 2015-2019 berdasarkan Bahasa Pengantar

Sumber: Data primer diolah, tahun 2020

Gambar 6 menunjukkan bahwa penggunaan bahasa pengantar pada penulisan artikel jurnal AGRISEP Universitas Bengkulu tahun 2015-2019, antara lain Bahasa Indonesia terdiri atas 88 artikel (96,70 \%), sedangkan penggunaan Bahasa Inggris terdiri atas 3 artikel (3,30\%). Dalam penulisan artikel, penulis diberikan kebebasan dalam memilih bahasa pengantar dalam Bahasa Indonesia ataupun bahasa asing seperti Bahasa Inggris. Pada jurnal AGRISEP penggunaan Bahasa Indonesia sebagai bahasa pengantar lebih tinggi daripada Bahasa Inggris. Hal ini sependapat dengan pendapat Natakusumah dalam Irianti (2017:37) yang menyatakan bahwa artikel Bahasa Indonesia lebih mendominasi daripada artikel berbahasa asing atau Bahasa Inggris.

Rata-rata bahasa yang digunakan dalam penulisan artikel pada jurnal AGRISEP Universitas Bengkulu 2015-2019 adalah Bahasa Indonesia. Hal ini bisa disebabkan karena ketentuan dari pihak jurnal AGRISEP yang tidak terlalu memaksakan penggunaan bahasa asing dalam penulisan artikelnya. Faktor lain yang bisa menjadi penyebab artikel Indonesia lebih banyak adalah keterbatasan kemampuan bahasa asing dari penulis. Hal ini dapat menjadi perhatian bagi pihak jurnal AGRISEP untuk menerbitkan lebih banyak artikel-artikel berbahasa asing guna meningkatkan akreditasi dan kualitas jurnal AGRISEP Universitas Bengkulu. Dengan demikian, jurnal AGRISEP bisa menjadi salah satu jurnal rujukan semua kalangan perguruan tinggi di Indonesia maupun di luar negeri dalam menyelesaikan penelitian. Dengan semakin banyak yang mengakses, maka h-indeks dari jurnal tersebut akan semakin tinggi.

\subsubsection{Produktivitas Pengarang}

Produktivitas pengarang ditentukan berdasarkan keterlibatan penulis dalam penulisan artikel baik secara individu maupun kolaborasi dengan penulis lain. Produktivitas pengarang merupakan jumlah hasil tulisan seorang pengarang yang dipublikasikan dalam kurun waktu tertentu. Dari 91 artikel pada jurnal AGRISEP Universitas Bengkulu 2015-2019, diperoleh 173 nama berbeda. Dari 173 nama tersebut, pengarang/penulis yang paling produktif adalah Sriyoto dengan jumlah artikel sebanyak 9 artikel atau artinya Sriyoto telah terlibat dalam penulisan artikel pada jurnal AGRISEP sebanyak 9 kali. Beliau merupakan salah seorang dosen yang berasal dari Universitas Bengkulu. Hal ini tidak menutup kemungkinan bagi penulis lain untuk menjadi penulis produktif di luar jurnal AGRISEP 
Universitas Bengkulu tahun 2015-2019. Penulis lain bisa juga menjadi penulis produktif pada kepenulisan artikel di jurnal yang berbeda baik dengan topik yang sama maupun yang lainnya.

\subsection{Karakteristik Artikel pada Jurnal AGRISEP Universitas Bengkulu tahun 2015-2019 Jumlah Artikel}

Jumlah artikel yang menjadi sampel penelitian dalam jurnal AGRISEP Universitas Bengkulu untuk lima tahun terakhir dihitung menggunakan rumus Slovin dan diperoleh bahwa jumlah artikel sebanyak 91 artikel. Bila dilihat dari tahun pertama terbit sampai sekarang, jumlah artikel pada jurnal AGRISEP Universitas Bengkulu terdiri atas 288 artikel yang terbit dari tahun 2004 sampai tahun 2019. Artikel sebanyak 288 artikel tersebut terdiri dari 16 volume dan 31 nomor jurnal. Masing-masing volume terdiri dari dua nomor jurnal, hanya satu volume yang memiliki satu nomor jurnal yaitu volume 8 tahun 2009 .

Tabel 1. Jumlah keseluruhan artikel jurnal AGRISEP Universitas Bengkulu tahun 2004-2019

\begin{tabular}{|c|c|c|c|c|c|}
\hline No. & Tahun & Volume & Nomor & $\begin{array}{l}\text { Jumlah } \\
\text { Artikel }\end{array}$ & $\%$ \\
\hline 1. & 2004 & 3 & 1 dan 2 & 8 & $2,78 \%$ \\
\hline 2. & 2005 & 4 & 1 dan 2 & 14 & $4,86 \%$ \\
\hline 3. & 2006 & 5 & 1 dan 2 & 11 & $3,82 \%$ \\
\hline 4. & 2007 & 6 & 1 dan 2 & 16 & $5,56 \%$ \\
\hline 5. & 2008 & 7 & 1 dan 2 & 12 & $4,12 \%$ \\
\hline 6. & 2009 & 8 & 2 & 7 & $2,43 \%$ \\
\hline 7. & 2010 & 9 & 1 dan 2 & 15 & $5,21 \%$ \\
\hline 8. & 2011 & 10 & 1 dan 2 & 23 & $7,99 \%$ \\
\hline 9. & 2012 & 11 & 1 dan 2 & 25 & $8,68 \%$ \\
\hline 10. & 2013 & 12 & 1 dan 2 & 20 & $6,94 \%$ \\
\hline 11. & 2014 & 13 & 1 dan 2 & 19 & $6,60 \%$ \\
\hline 12. & 2015 & 14 & 1 dan 2 & 21 & $7,29 \%$ \\
\hline 13. & 2016 & 15 & 1 dan 2 & 25 & $8,68 \%$ \\
\hline 14. & 2017 & 16 & 1 dan 2 & 21 & $7,29 \%$ \\
\hline 15. & 2018 & 17 & 1 dan 2 & 20 & $6,94 \%$ \\
\hline 16. & 2019 & 18 & 1 dan 2 & 31 & $10,76 \%$ \\
\hline Total & & 16 & 31 & 288 & $100 \%$ \\
\hline
\end{tabular}

Tabel 1 memperlihatkan publikasi artikel pada jurnal AGRISEP Universitas Bengkulu tahun 2004-2019 yang memberikan gambaran bahwa jumlah artikel yang dipublikasi sangat bervariasi dan terus mengalami peningkatan setiap tahunnya. Bila diamati lebih jauh, terlihat bahwa jumlah artikel yang paling banyak ialah pada tahun 2019 sebanyak 31 artikel. Perbedaan jumlah artikel yang berbeda setiap tahun disebabkan oleh beberapa faktor, yaitu jumlah artikel yang dipublikasi semakin bertambah, banyaknya artikel yang dipublikasi pada jurnal AGRISEP ditentukan berdasarkan panjang dari masing-masing artikel yang diterima oleh pihak redaksi. Faktor lainnya adalah perkembangan artikel pada jurnal AGRISEP Universitas Bengkulu mengalami peningkatan jumlah artikel setiap tahunnya namun tidak tetap jumlahnya.

\subsubsection{Panjang Artikel}

Penghitungan Panjang artikel pada jurnal AGRISEP Universitas Bengkulu tahun 2015-2019 ditentukan berdasarkan banyak halaman dari setiap artikel yang dikelompokkan menjadi tiga kelompok yaitu 6-10 halaman; 11-15 halaman; dan 16-20 halaman. 


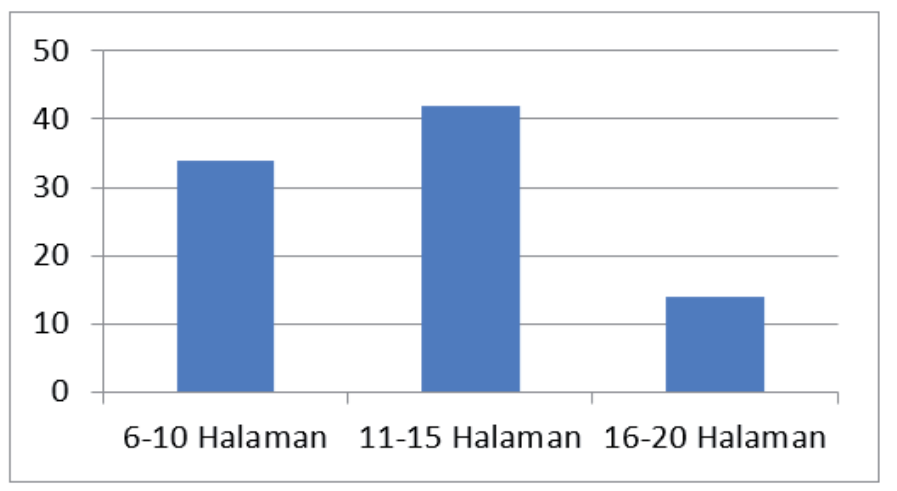

Gambar 7. Jumlah artikel pada Jurnal AGRISEP Universitas Bengkulu tahun 2015-2019 berdasarkan Panjang Artikel

Sumber: Data primer diolah, tahun 2020

Pada Gambar 7 menunjukkan bahwa artikel yang memiliki panjang 6-10 halaman terdiri atas 34 artikel (37,36 \%), artikel yang memiliki panjang 11-15 halaman terdiri atas 42 artikel (56,15\%), sedangkan artikel yang memiliki panjang 16-20 terdiri atas 15 artikel (15,48 \%). Hampir keseluruhan artikel pada jurnal AGRISEP Universitas Bengkulu tahun 2015-2019 telah memenuhi panduan penulisan artikel. Adapun ketentuan panjang halaman artikel pada jurnal AGRISEP Universitas Bengkulu adalah maksimal 14 halaman. Panjang halaman setiap artikel pada jurnal AGRISEP Universitas Bengkulu sangat berpengaruh terhadap jumlah artikel yang akan diterbitkan pada jurnal. Penerbitan artikel setiap volume pada jurnal AGRISEP Universitas Bengkulu dibatasi oleh panjang halaman dengan target 400 halaman per tahun terbit. Jadi penerbitan artikel pada jurnal AGRISEP Universitas Bengkulu bukan berdasarkan banyak artikelnya namun jumlah halaman artikelnya.

Pedoman penulisan artikel yang telah ditetapkan oleh jurnal AGRISEP Universitas Bengkulu menyatakan bahwa panjang artikel tidak boleh melebihi 14 halaman termasuk referensi dan lampiran. Namun berdasarkan hasil penelitian yang telah dilakukan, terdapat sebanyak 15 artikel (15,48 \%) yang tidak mematuhi aturan tersebut. Hal ini dapat menjadi masukan bagi redaksi Jurnal AGRISEP Universitas Bengkulu dalam menerima dan mempublikasi Jurnal.

\subsubsection{Jumlah Kata Kunci}

Jumlah kata kunci ditentukan berdasarkan banyaknya kata kunci pada masing-masing artikel pada jurnal AGRISEP Universitas Bengkulu tahun 2015-2019. Jumlah kata kunci dihitung berdasarkan kata yang dipisah oleh tanda baca (,). Dari 91 artikel Jurnal AGRISEP Universitas Bengkulu tahun 2015-2019 ditemukan jumlah kata kunci sebagai berikut.

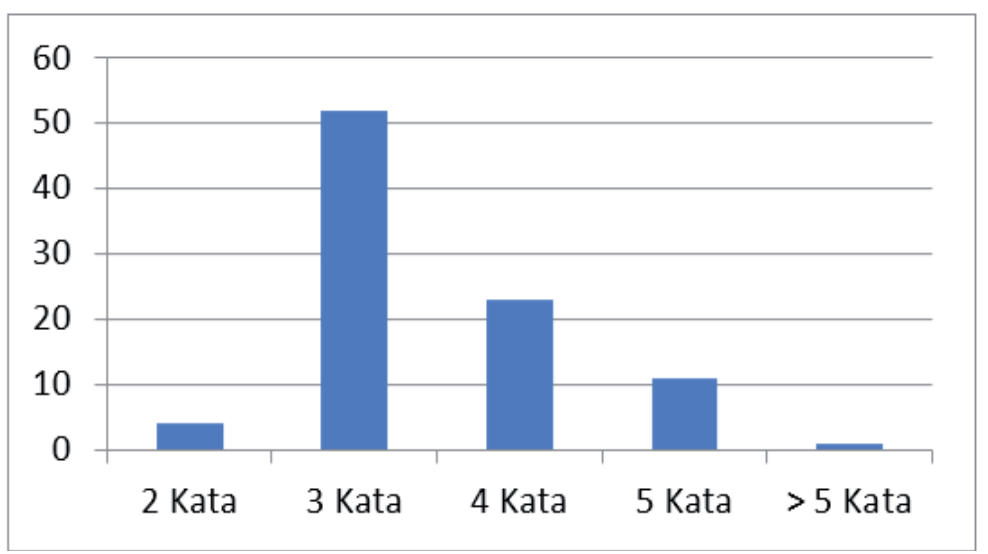

Gambar 8. Jumlah artikel Jurnal AGRISEP Universitas Bengkulu tahun 2015-2019 berdasarkan Kata Kunci 
Berdasarkan Gambar 8, artikel yang memiliki dua kata kunci terdiri atas 4 artikel (4,40\%), artikel yang memiliki tiga kata kunci terdiri atas 52 artikel $(51,14 \%)$, artikel yang memiliki empat kata kunci terdiri atas 23 artikel $(25,27 \%)$, artikel yang memiliki lima kata kunci terdiri atas 11 artikel (12,09\%), dan artikel yang memiliki kata kunci $>5$ terdiri atas 1 artikel (1,10\%). Berdasarkan hasil tersebut dapat disimpulkan bahwa jumlah kata kunci yang paling banyak di jurnal AGRISEP adalah sebanyak tiga kata kunci. Dari hasil ini dapat dilihat bahwa para penulis telah memahami kaidah-kaidah dalam pembuatan kata kunci.

Pemilihan kata kunci pada sebuah artikel biasanya disesuaikan dengan subjek pokok yang menjadi bagian utama yang dibahas dalam penelitian. Pihak jurnal AGRISEP Universitas Bengkulu sendiri tidak memiliki ketentuan khusus berapa jumlah kata kunci yang perlu dibuat untuk sebuah artikel. Biasanya, pemisah antara satu kata kunci dengan kata kunci yang lainnya adalah tanda koma. Banyaknya jumlah kata kunci pada sebuah artikel umumnya ditentukan oleh masing-masing penerbit. Namun sebaiknya jumlah kata pada sebuah artikel terdiri atas 3-6 istilah.

\subsubsection{Panjang Abstrak}

Panjang abstrak dihitung menggunakan Microsoft Word yaitu dengan memasukkan abstrak masingmasing artikel ke dalam Microsoft Word sehingga otomatis memunculkan banyak kata pada abstrak. Abstrak yang dihitung panjangnya pada artikel jurnal AGRISEP Universitas Bengkulu tahun 20152019 adalah abstrak yang menggunakan Bahasa Inggris. Hal ini dikarenakan terdapat beberapa artikel yang tidak memiliki abstrak dalam Bahasa Indonesia.

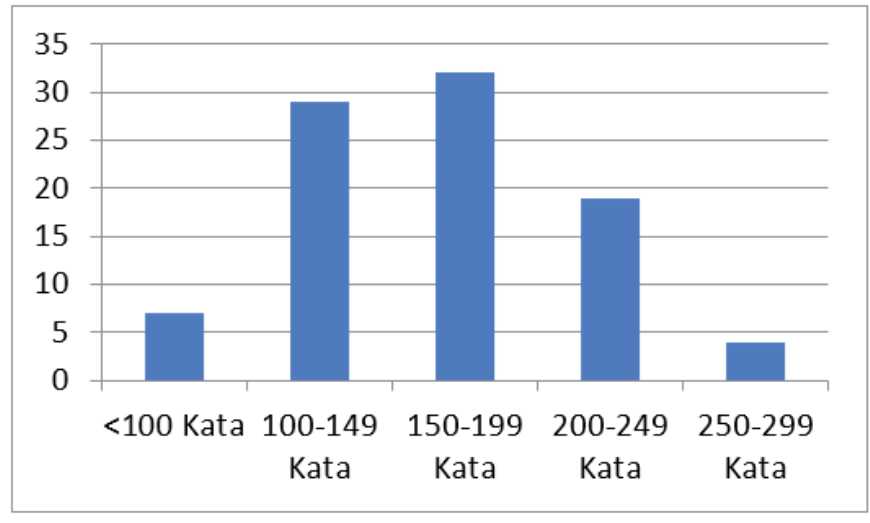

Gambar 9. Jumlah artikel jurnal AGRISEP Universitas Bengkulu tahun 2015-2019 berdasarkan Panjang Abstrak Sumber: Data primer diolah, tahun 2020

Berdasarkan gambar 11, artikel yang memiliki panjang abstrak $<100$ kata terdiri atas 7 artikel (7,69\%), artikel yang memiliki panjang abstrak 100-149 kata terdiri atas 29 artikel (31,87\%), artikel yang memiliki panjang abstrak 150-199 kata terdiri atas 32 artikel (35,16\%), artikel yang memiliki panjang abstrak 200-249 kata terdiri atas 19 artikel (20,88 \%), dan artikel yang memiliki panjang abstrak 250-299 kata terdiri atas 4 artikel (4,40\%). Berdasarkan hasil di atas dapat disimpulkan bahwa mayoritas penulis jurnal telah memahami kaidah pembuatan abstrak. Hal ini ditunjukkan dengan rata-rata artikel dalam jurnal AGRISEP Universitas Bengkulu tahun 2015-2019 telah memenuhi pedoman penulisan artikel tentang panjang abstrak. Adapun ketentuan panjang abstrak untuk setiap artikel pada jurnal AGRISEP Universitas Bengkulu terdiri atas 100-250 kata. Dari hasil penelitian terdapat beberapa artikel yang memiliki panjang abstrak $>100$ dan $>250$, dalam hal ini abstrak berbahasa Inggris. 


\subsection{Jenis-jenis Literatur yang digunakan dalam Artikel}

Terdapat banyak jenis literatur yang digunakan sebagai referensi dalam penulisan artikel pada jurnal AGRISEP Universitas Bengkulu tahun 2015-2019. Dari 91 artikel, terdapat 1.010 kutipan dari 10 jenis literatur yang terdiri atas buku, jurnal, skripsi, tesis, disertasi, prosiding, undang-undang, website, terbitan Badan Pusat Statistik, dan seminar nasional. Berikut hasil temuan dari jenis-jenis literatur yang digunakan pada jurnal AGRISEP Universitas Bengkulu tahun 2015-2019.

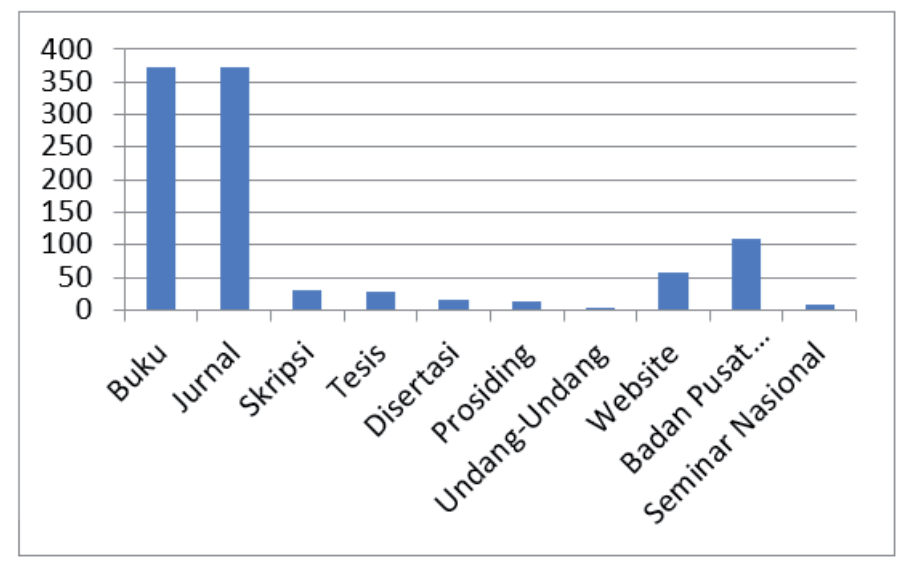

Gambar 10. Jenis-Jenis Literatur yang dikutip pada jurnal AGRISEP Universitas Bengkulu tahun 2015-2019

Sumber: Data primer diolah, tahun 2020

Berdasarkan Gambar 12, jenis literatur dari buku terdiri atas 372 kutipan (36,83\%), sedangkan jurnal terdiri atas 373 kutipan (36,93\%), skripsi terdiri atas 31 kutipan (3,07\%), tesis terdiri atas 29 kutipan $(2,87 \%)$, disertasi terdiri atas 16 kutipan (1,58\%), prosiding terdiri atas 12 kutipan $(1,19 \%)$, undang-undang terdiri atas 4 kutipan $(0,40 \%)$, website terdiri atas 57 kutipan $(5,64 \%)$, terbitan Badan Pusat Statistik terdiri atas 108 (10,69\%), terakhir seminar nasional terdiri atas 8 kutipan $(0,79 \%)$. Berdasarkan hasil analisis, literatur yang paling banyak dikutip adalah jurnal, yaitu sebanyak 373 kutipan (36,93 \%). Hasil tersebut menunjukkan bahwa penulis AGRISEP telah memahami pentingnya sumber literatur jurnal dalam penulisan tulisan ilmiah.

Faktor yang menentukan jurnal sebagai sumber literatur yang paling banyak digunakan pada jurnal adalah karena perkembangan jurnal yang semakin meningkat, up to date, mudah diakses, serta merupakan hasil karya tulis ilmiah yang selalu berkembang. Jurnal juga merupakan kajian ilmiah yang sangat baik digunakan untuk menghasilkan karya ilmiah juga. Selain Itu, jurnal juga menjadi salah satu referensi yang dapat dijadikan sebagai acuan karena isinya yang ringkas dan mudah dimengerti.

Hal ini sependapat dengan pendapat Marlina (2017:152) yang menyatakan bahwa banyaknya sitiran terhadap jurnal ilmiah disebabkan karena jurnal merupakan referensi yang lebih baru dibandingkan dengan literatur-literatur lainnya, dan di dalam jurnal memuat informasi-informasi yang mutakhir. Dengan demikian, penggunaan jurnal sebagai referensi sangat banyak digunakan oleh penulis dikarenakan informasi di dalam jurnal lebih rinci, mudah dipahami, dan selalu memiliki informasi yang terbaru (up to date). Dalam perkembangannya, jurnal tidak hanya ditemukan dalam media cetak saja, melainkan telah dikembangkan ke dalam bentuk elektronik yang memudahkan pengguna untuk menemukannya. Hal ini yang membuat eksistensi jurnal online lebih cepat perkembangannya dibandingkan dengan jenis literatur yang lain. 


\section{KESIMPULAN}

Berdasarkan hasil penelitian dapat disimpulkan bahwa karakteristik kepenulisan dan artikel pada Jurnal AGRISEP Universitas Bengkulu tahun 2015-2019 cukup bervariasi berdasarkan indikator dalam penelitian. Hal ini dapat dilihat dari beberapa indikator pada karakteristik kepengarangan yaitu: 1) penulis laki-laki lebih banyak berkontribusi dalam penulisan artikel dibandingkan penulis perempuan, yaitu sebanyak 54,08 \%; 2) instansi asal dimana Universitas Bengkulu menyumbang artikel sekitar 41 artikel; 3) penulis dosen lebih banyak berkontribusi dibandingkan profesi lainnya dengan persentase sebesar 50,43\%; 4) tingkat pendidikan magister lebih banyak berkontribusi dalam penulisan artikel di (presentase sebesar 46,49\%) 5) dalam hal jumlah penulis, penulis yang terdiri dari tiga orang lebih banyak daripada yang lainnya dengan jumlah pesentase sebesar $52,75 \%$. Berdasarkan karakteristik artikel, diperoleh bahwa: 1) dari tahun 2004-2019, jumlah artikel terbanyak ialah 31 artikel yang terbit pada tahun 2019; 2) penggunaan Bahasa Indonesia lebih banyak dibandingkan penggunaan bahasa asing dengan persentase $96,70 \%$; 3) dalam hal produktifitas, pengarang yang paling produktif adalah Sriyoto; 4) dalam hal panjang artikel, jumlah artikel 11-15 halaman lebih tinggi daripada yang lain dengan persentase $56,15 \%$; 5) kata kunci pada jurnal AGRISEP mayoritas terdiri dari tiga kata kunci dengan persentase 51,14 \%; 6) artikel yang memiliki panjang abstrak 150-199 kata lebih banyak daripada yang lainnya dengan persentase sebesar 35,16\%. Karakteristik kepenulisan dan artikel ini dapat digunakan oleh institusi dan pengelola jurnal AGRISEP untuk mengevaluasi jurnal dan meningkatkan kualitas jurnal dalam akreditasi jurnal.

\section{DAFTAR PUSTAKA}

Aliyu, M. 2011. Author Productivity And Colaboration Among Academic Scientists In Modibbo Adama University of Technology, Yola. The Information Manage, Vol. 11, No.1-2: 32-35.

Aprilliana, R. 2014. Pengaruh Lingkungan Kerja, Kompetensi dan Pemberdayaan Terhadap Kinerja Pada Guru Sertivikasi SMA Negeri Kecamatan Kota Bumi Selatan Tahun Pelajaran 2013/2014 (Universitas Lampung).

Guninda, Z., Rukiyah, \& Christiani, L. 2015. Analisis Sitiran Jurnal Pada Skripsi MAmahasiswa Jurusan Ekonomika Dan Bisnis Universitas Diponegoro. Jurnal Ilmu Perpustakaan,Vol.4,No.2:2-8.

Irianti, P. 2017. Karakteristik Kepenulisan Dan Karakteristik Artikel Pada Jurnal Psikologi Universitas Gadjah Mada: Kajian Bibliometrika. Jurnal Dokumentasi Dan Informasi, Vol.38,No.1:27-44.

Jatmiko, W., Santoso, H. B., Purbarani, S. C., Syulistyo, A. R., Purnomo, D. M. J., Firmansyah, D., ... Laili, N. A. 2015. Panduan Penulisan Artikel Ilmiah. Depok: Universitas Indonesia.

Junandi, S., \& Zulaikha, S. R. 2010. Analisis Sitiran Artikel Jurnal Luar Negeri Pada Laporan Penelitian di Lembaga Penelitian dan Pengabdian Kepada Masyarakat UGM yang Dibiayai Badan Litbang Pertanian Departemen Pertanian Tahun 2007. Berkala Ilmu Perpustakaan Dan Informasi,Vol.6,No.1,14-22.

Marlina, E., \& Kusumaningrum, D. 2017. Analisis Karakteristik Literatur yang Disitir dalam Artikel Jurnal Ilmiah Indonesia. Jurnal Dokumentasi Dan Informasi, Vol. 7,: 143-156.

Pattah, S. H. 2013. Pemanfaatan Kajian Bibliometrika Sebagai Metode Evaluasi dan Kajian dalam Ilmu Perpustakaan dan Infoemasi. Jurnal Ilmu Perpustakaan, Informasi Dan Kearsipan, Vol.1,No.1:47-57.

Pohan, F. 2014. Analisis Bibliometrika Terhadap Jurnal Ilmiah Terbitan Indonesia Pada Database Scimago Journals And Country Rank.

Savitri, S. 2018. Kajian Bibliometrik Terhadap Karakteristik Kepenulisan dan Artikel Pada Buletin Pertanian Perkotaan. Jurnal Perpustakaan Pertanian, Vol.27:23-29.

Tupan, Rahayu, R. N., Rachmawati, R., \& Rahayu, E. S. R. 2018. Analisis Bibliometrik Perkembangan Penelitian Bidang Ilmu Instrumentasi. Jurnal Dokumentasi Dan Informasi, Vol. 3, No.2 : 135-149. 